\title{
Defaults in bank loans to SMEs during the financial crisis
}

\author{
Fábio Dias Duarte • Ana Paula Matias Gama • \\ Mohamed Azzim Gulamhussen
}

Accepted: 14 September 2017 /Published online: 7 October 2017

(C) Springer Science+Business Media, LLC 2017

\begin{abstract}
We investigate the role of (business) collateral and (personal) guarantees alongside small and medium enterprise (SME), lending bank and loan characteristics, macroeconomic conditions, sectors, and geographic locations while controlling for unobserved time effects in predicting default at the peak of the financial crisis. First, we find a positive relation between collateral and default, and a negative relation between guarantees and default. Second, we find a negative relation between the joint influence of collateral and high credit score, and a positive relation between the joint influence of collateral and low credit score and default. We also find a negative relation between the joint influence of guarantees and high credit score. These findings are relevant for SME policies aimed at facilitating access to credit, reducing the cost of borrowing, and decreasing default; risk management of banks; and the application
\end{abstract}

F. D. Duarte

IPP-ESTG \& NECE, Rua do Curral-Casa do Curral, Margaride, 4610-156 Felgueira, Portugal

e-mail: fdd@estg.ipp.pt

A. P. M. Gama $(\bowtie)$

UBI \& NECE, Estrada do Sineiro-Polo IV, 6200-209 Covilhã,

Portugal

e-mail: amatias@ubi.pt

M. A. Gulamhussen

ISCTE-IUL Business School \& Vlerick Business School, Manhattan Center Bolwerklaan, 21-32 1210 Brussels, Belgium e-mail: mohamed.azzim@iscte.pt; azzim.gulamhussen@vlerick.com of theories of financial economics in the context of a financial crisis.

Keywords Corporate financing decisions · Financial crisis · Government policy and regulation $\cdot$ Banks

JEL classification $\mathrm{D} 82 \cdot \mathrm{G} 01 \cdot \mathrm{G} 18 \cdot \mathrm{G} 20$

\section{Introduction}

The prediction of default in bank loans to small and medium enterprises (SMEs) has been a concern of managers, academics, and policymakers for several decades (Dietrich and Kaplan 1982; Laitinen 1992). The topic acquired renewed interest in the 1990s with the adoption and implementation of the Basel Capital Accords, which not only play a vital role in the definition of limit facilities, pricing, and risk management, but also initiated the requisite for banks to determine risk-based capital requirements on the basis of the internal ratings ascribed to their customers; in addition, they required supervisors to detect early warning signals in bank loan portfolios and regulators to assess pressure in the corporate sector (Siddiqi 2006; Glantz and Mun 2008).

The 2007-2009 financial crisis enhanced concerns about bank credit at several levels. ${ }^{1}$ SMEs were in need of access to bank financing to implement their projects in an adverse setting. Policymakers were required to design monetary policy to unlock growth in ailing

${ }^{1}$ In some countries, the crisis extended beyond 2009. 
economies, to gauge the potential impact of defaults in bank loans on the solvability and liquidity of banks, and their consequent impact on the overall stability of the financial system. This special setting provided academics with an exceptional laboratory to test their theories (Abreu and Gulamhussen 2013). We contribute to this emerging strand of literature by investigating the role of (business) collateral and (personal) guarantees alongside SME, bank and loan characteristics, and macroeconomic conditions in predicting default at the peak of the financial crisis.

The literature on defaults has been developed along two distinct lines of inquiry. One seeks to develop models that facilitate the determination of the factors that predict default and their influence on the probability of default (Westgaard and Wijst 2001). Another seeks to identify the financial (Laitinen 1992) and non-financial factors (Dietrich and Kaplan 1982) that predict default. In this latter vein, Bhimani et al. (2014) shed light on the role of both the personal liability of owners of SMEs and financial reporting information of SMEs in reducing default. We extend this recent study along three main lines. First, we use data straight from the credit portfolio of a bank. Second, our data allow us to assess the role of collateral and guarantees alongside SME and bank characteristics, macroeconomic conditions, sectors, and geographic locations in which the SMEs operate. Third, our data cover the peak of the 2007-2009 crisis, an exceptionally stressful setting for which we are able to ascertain the predictors and associated probabilities of default, thus allowing us to draw implications for SME financing, policymaking and the theory of corporate finance during financial crisis situations.

The role of collateral and guarantees is particularly relevant in the context of the financial crisis. Bank lending to SMEs is commonly fraught with information asymmetries and consequently involves higher screening and monitoring costs (Grunert and Norden 2012). Banks respond to information asymmetries by retracting on lending and charging higher interest rates (Stiglitz and Weiss 1981) or lending with collateral regardless of the project's quality (Chan and Kanatas 1985). ${ }^{2}$ During financial crises, banks may further retract on new lending to SMEs due to heightened capital requirements imposed by regulators or to liquidity freezes (Bartoli

\footnotetext{
${ }^{2}$ Banks with more sophisticated lending technology overcome information asymmetries by building long-term relationships with SMEs (Berger and Udell 2002).
}

et al. 2013). Under these exceptional situations, banks may secure collateral from SMEs or guarantees from the owners of SMEs to obtain their commitment to exert effort (Voordeckers and Steijvers 2006; Menkhoff et al. 2012) and to minimize risk-taking (Stulz and Johnson 1985).

A particular feature of our data is that we are able to discern the collateral and guarantees of owners. ${ }^{3}$ With collateral, SMEs are liable up to the amount of collateral that they post; with guarantees, owners are liable beyond their business assets. Collateral removes the downside risk of owners while preserving the upside potential. Guarantees amplify the risk of owners to an unlimited extent. This uneven payoff does not ensure a lower bound of zero in the payoff of equity and discourages risk-seeking behavior (Bhimani and Ncube 2006). ${ }^{4}$ Bhimani et al. (2014) test the role of owner liability alongside financial reporting information on SMEs in predicting default during a stable financial setting. Our data enables us to address the role of owner liability in conjunction with the credit scores of SMEs and the financial tension they experienced during the financial crisis, loan characteristics, macroeconomic conditions, sectors, and geographic locations in which the SMEs operate while controlling for unobserved time-specific effects.

We address the setting of our study in Section 2 and construct the hypotheses in Section 3; describe the data and our model in Section 4; report the findings and robustness tests in Section 5; and summarize the conclusions and implications of our study in Section 6.

\section{The uniqueness of the setting}

Macroeconomic conditions The 2007-2009 financial crisis is now considered the worst since the Great Depression of 1929. It is commonly believed that the collapse of Lehman Brothers rapidly propagated to $\mathrm{Eu}-$ rope through interbank markets. The impairment in the

\footnotetext{
$\overline{{ }^{3} \text { Ang et al. (1995) }}$ and Avery et al. (1998) differentiate business and personal risks in the context of SMEs in the USA; Peltoniemi and Vieru (2013) assess the influence of personal guarantees in the pricing of transaction and relationship loans extended by banks to SMEs in Finland.

${ }^{4}$ Financial option models use stock returns and volatility as inputs, which limit their application to firms listed on stock markets (Duffie and Singleton 2003).
} 
functioning of interbank markets soon led to a banking crisis across the globe (Haughwout et al. 2009).

Policymakers in Europe initially responded to the banking crisis by bailing out banks with the aim of maintaining the stability of the financial system and the supply of credit to the economy. Subsequently, through the European Central Bank (ECB), they embarked on a huge liquidity injection program in the economy by sequentially taking public debt, mortgagebacked securities, and SME loan portfolios as collateral. In parallel, through the European Investment Bank (EIB), they undertook a massive guarantee program to facilitate the supply of credit to the economy, especially to SMEs. These enormous efforts significantly alleviated the credit crunch. Nevertheless, the crisis inevitably unsettled the supply of credit to the economy with consequences for economic growth.

Despite the marked efforts of policymakers, banks in Europe retracted on lending to SMEs during the financial crisis. In situations where banks did not retract on lending, they secured business and personal guarantees to extend loans to SMEs, with the aim of withstanding the potential adverse outcomes of the financial crisis. This setting provides an exceptional opportunity to extend the literature assessing the role of financial reporting and non-financial information in predicting default on bank loans to SMEs in the context of a stable economic setting (Bhimani et al. 2014; Westgaard and Wijst 2001) to a stressed economic scenario. Our findings can further contribute to the understanding of the consequences of the financial crisis and in particular of the disruption in the supply of credit to SMEs.

Institutional infrastructure The impact of disruption in the supply of credit, especially for SMEs in Europe, could have been alleviated if these entities had been able to tap into alternative sources of finance though the issuance of equity, bonds, or hybrid instruments in capital markets or, alternatively, if they had had multiple banking relationships. Unlike the USA, Europe has a significantly bank-dominated financial infrastructure: SMEs rely more extensively on bank credit due to the lower development of capital markets. For example, Krivogorsky (2011) shows that even in countries where capital markets are well-developed, the level of separation between ownership and management remains very low compared to the USA. Gama and Van Auken (2015) show that SMEs in our context have a single bank relationship and use trade credit as an alternative source of credit. According to the ECB, $70 \%$ of SMEs in the Euro area use bank-based financing via loans, overdrafts, or lines of credit; $24 \%$ use trade credit; and only $2.2 \%$ of SMEs use market-based financing via the issuance of debt or equity securities (ECB 2010).

Economic development indicators Despite the diversity of the legal and judicial framework in Europe, it also suffers as a result of the inefficiency of these frameworks in some countries. The countries in the latter situation are particularly different from the USA in terms of legal rights, the time required to enforce contracts, and the efficiency of the judicial system. For example, the World Bank (2017) economic development indicator on legal rights $(0=$ weak; $12=$ strong $)$ around the world shows that Portugal scores 2 (Europe scores 6.4) whereas the USA scored 11. Similarly, whereas in Portugal it takes on average 547 (in Europe 460) days to enforce a contract, in the USA this takes 420 days. When we examine the quality of judicial processes $(0=$ poor; $18=$ strong $)$, Portugal scores 12.5 (Europe scores 10.8) while the USA scores 13.8.

These economic development indicators highlight significant differences in the legal and judicial structures across Europe in general (Portugal in particular) and the USA, which makes the study particularly interesting. Moreover, the legal and judicial structures increase the need of banks relying on the personal guarantee of owners to secure loans as these guarantees not only extend the liability of owners but also facilitate the seizure of owners' assets that can be transferred without significant time delay and judicial costs. $^{5}$

\section{Hypotheses}

We build our hypotheses from previous studies on the prediction of default in bank loans extended to SMEs. We group our hypotheses into SME, bank and loan characteristics, macroeconomic conditions, sectors, and geographic locations.

\footnotetext{
$\overline{5}$ The inefficiency of the judicial system compared to the USA inhibits banks from repossessing business assets swiftly. Banks may repossess these assets after a prolonged period but their value may deteriorate.
} 


\subsection{SME characteristics}

Banks develop credit scores to guide credit, limit facilities, and pricing decisions (Siddiqi 2006; Glantz and Mun 2008). SMEs are ascribed internal scores by banks following an analysis of their financial reporting and non-financial information. SMEs that receive a high credit score are expected to default less than those receiving a low credit score (Butera and Faff 2006). We thus expect a negative relation between high credit score and default (H1a) and a positive relation between low credit score and default during the financial crisis (H1b). The financial tension faced by the SME to secure new loans, particularly during a crisis situation, indicates higher potential of default (Bartoli et al. 2013). We expect a positive relation between financial tension and default (H1c).

\subsection{Bank characteristics}

Banks compliant with the Basel Capital Accords need to carry minimum capital for their banking and trading books. The banking book comprises loans extended to SMEs that carry a specific weight for the calculation of minimum required capital (Jacobson et al. 2005). This capital is supposed to allow banks to withstand expected and unexpected losses during crisis situations (Saurina and Trucharte 2004). We expect a negative relation between bank capital and default during the crisis situation $(\mathrm{H} 2)$.

\subsection{Loan characteristics: size}

Loan characteristics also influence default. Loan size is one such characteristic. Compared to small loans, large loans are granted to finance large-scale projects which may be complex and risky (Derban et al. 2005). We expect a positive relation between loan size and default (H3).

\subsection{Loan characteristics: collateral and guarantees}

Loans that are secured with collateral or guarantees will be more negatively related to default than loans that are not secured with collateral or guarantees because the former mitigate moral hazard (Ono and Uesugi 2009). We expect a negative relation between collateral (H4a) and guarantees (H4b) and default.
There are two circumstances under which loans may be secured with collateral or guarantees. First, better-rated SMEs may be willing to post collateral or pledge guarantees of their owners to signal their quality (Bester 1985). Second, banks may force poorly rated SMEs to post collateral or pledge guarantees to withstand losses from eventual default of these firms (Holmstrom and Tirole 1997). We expect a negative relation between the joint influence of better rated SMEs and collateral $(\mathrm{H} 4 \mathrm{c} 1)$, and guarantees ( $\mathrm{H} 4 \mathrm{~d} 1)$, and default; and a positive relation between the joint influence of poorly rated SMEs and collateral $(\mathrm{H} 4 \mathrm{c} 2)$, and guarantees $(\mathrm{H} 4 \mathrm{~d} 2)$, and default.

\subsection{Macroeconomic conditions}

Macroeconomic conditions can significantly influence the ability of SMEs to repay their loans. Under good macroeconomic conditions, SMEs will be able to repay their loans or delay default, whereas SMEs experiencing difficulties in stressful macroeconomic conditions may not be able to delay default on their loans (Westgaard and Wijst 2001). We expect a negative (positive) relation between good (stressful) macroeconomic conditions and default (H5).

\subsection{Sectors and geographic locations}

Different industries and geographic regions may exhibit distinct opportunities and challenges. We distinguish between the sectors [primary (control variable within this group of variables), secondary, and tertiary] and the geographic locations [North, Center, Lisbon and Vale do Tejo, Alentejo, South (Algarve), Madeira, Azores, and the Special Administrative Region (control variable within this group of characteristics)] to capture their idiosyncratic influence on default. ${ }^{6}$ We do not hypothesize any prior relation between the sectors $(\mathrm{H} 6 \mathrm{a}-\mathrm{c})$ and regions $(\mathrm{H} 7 \mathrm{a}-\mathrm{h})$ and default.

\footnotetext{
$\overline{{ }^{6}}$ The sectors are classified according to the classification used by the bank that provided the data. The locations are classified according to the regional office that is responsible for the loan.
} 


\section{Data, variables, and method}

\subsection{Sample}

We use proprietary and confidential financial data on loans extended to SMEs by a major commercial bank operating in Portugal, gathered between January 2007 and December 2010, a period of severe crisis that coincided with the liquidity crunch in the interbank market. ${ }^{7}$ We define SMEs as legal entities with fewer than 250 employees and annual business volumes of less than $€ 50$ million or assets that do not exceed $€ 43$ million (European Commission (EC) 2003). Our data comprise 5898 loans granted to SMEs. European law mandates that all institutions report every loan above $€ 50$ on a monthly basis to their central banks. This information is maintained in the central credit register of central banks. Thus, when granting a new loan, a bank can observe the total amount borrowed from other banks and whether the applicant has any overdue loans. We exclude mortgage-backed loans and loans extended to unincorporated businesses because the assets of the owner are by their nature not separable from the assets of the business; therefore, these loans require separate analysis (Berger and Udell 2002).

\subsection{Variables}

Our data include one dependent variable: Default is binary and equals 1 if the SME defaults after obtaining the loan and 0 otherwise. The data also include four distinct groups of independent variables: SME, bank, loan characteristics, and macroeconomic conditions; and sectors, and geographic locations. SME characteristics include credit scores and financial tension. Credit score is the internal rating ascribed by the bank to the SME. This score combines data on the SME's financial reporting and non-financial information: high credit score equals 1 if the score is classified as AAA to BB; medium credit score equals 1 if the score is classified as $\mathrm{BB}-$ to $\mathrm{B}-$; low credit score equals 1 if the score is classified as $\mathrm{CCC}$ to $\mathrm{C}$; it equals 0 otherwise. Financial tension is the ratio of the loan amount approved by the bank to the firm and the total credit available to this firm

\footnotetext{
${ }^{7}$ There are two reasons for including data for 2010 in our analysis: First, although the global financial crisis occurred in 2007-9, its impact on our setting extended beyond this, and culminated in a bailout of the country in 2011. Second, as common to the study of defaults, we use data for 2007 (2008 and 2009) to predict defaults in 2008 (2009 and 2010).
}

in the entire financial system. Bank characteristics include the Tier 1 capital, the ratio of total equity minus revaluation reserves to risk-weighted assets. Loan characteristics include the loan size in euros and collateral/ guarantees. Collateral equals 1 if the borrower has offered firm assets to secure the loan, and guarantees equals 1 if the borrower has pledged a personal guarantee to secure the loan, and 0 otherwise. Macroeconomic conditions include change in the growth rate of gross domestic product from 1 year to another. Sectors and geographic location variables include dummies for the primary, secondary, and tertiary sectors; and dummies for the North, Center, Lisbon and Vale do Tejo, Alentejo, South (Algarve), Madeira, Azores, and the Special Administrative Region (see also footnote 6).

\subsection{Descriptive and univariate statistics}

We report the descriptive statistics of our sample in Table 1. In our sample, $27 \%$ of SMEs that received new loans defaulted, a significantly higher proportion than the $6 \%$ observed under stable macroeconomic economics conditions (see for example in Bhimani et al. 2014). SME characteristics show that $45 \%$ were ascribed high credit score, $49 \%$ medium credit score, and $6 \%$ low credit score; on average, they drew $36 \%$ of their total credit from the bank. The bank in our sample had an average Tier I capital of $7.79 \%$, which is above the minimum under the Basel Capital Accords at the time. The average loan size was $€ 117,000 ; 14 \%$ of SMEs posted collateral and $57 \%$ pledged guarantees. ${ }^{8}$ The lower proportion of collateral compared to guarantees is common in countries with weak legal rights and high (large) contract enforcement costs (periods). In the sample, $4 \%$ of SMEs are from the primary sector, $39 \%$ from the secondary sector, and 58\% from the tertiary sector. In addition, $32 \%$ of SMEs in the sample are from the North, 32\% from the Center, and 17\% from Lisbon and Vale do Tejo, 9\% from Alentejo, 4\% from Azores, $3 \%$ from the South (Algarve), 1\% from Madeira, and $3 \%$ from the Special Administrative Region.

Focusing on the interaction of collateral with credit score variables, our descriptive statistics reveal that $6 \%$ of SMEs that posted collateral had a high credit score,

\footnotetext{
${ }^{8}$ From the SMEs' perspective, this could be related to the inability to subsequently dispose of the assets for alternative uses or to the absence of assets to post collateral. From the banks' perspective, this could also be related to the quality of assets. Understanding these issues constitute interesting avenues for future research.
} 
Table 1 Descriptive statistics for variables used in the study

\begin{tabular}{|c|c|c|c|c|c|c|}
\hline & Observations & Type & Mean & Standard deviation & Minimum & Maximum \\
\hline \multicolumn{7}{|l|}{ Dependent variables } \\
\hline Default & 5898 & Yes $=1 ; \mathrm{No}=0$ & 0.267 & 0.442 & 0 & 1 \\
\hline \multicolumn{7}{|l|}{ Independent variables } \\
\hline \multicolumn{7}{|l|}{ SME characteristics } \\
\hline High credit score & 5898 & Yes $=1 ; \mathrm{No}=0$ & 0.447 & 0.497 & 0 & 1 \\
\hline Medium credit score & 5898 & Yes $=1 ;$ No $=0$ & 0.494 & 0.500 & 0 & 1 \\
\hline Low credit score & 5898 & Yes $=1 ;$ No $=0$ & 0.058 & 0.233 & 0 & 1 \\
\hline Financial tension & 5898 & Continuous (\%) & 36.107 & 27.873 & 0.024 & 100 \\
\hline \multicolumn{7}{|l|}{ Bank characteristics } \\
\hline Tier 1 capital & 5898 & Continuous (\%) & 7.790 & 1.071 & 6.2 & 8.9 \\
\hline \multicolumn{7}{|l|}{ Loan characteristics } \\
\hline Size & 5898 & Continuous $(\mathrm{k} €)$ & 117,465 & 159,279 & 5000 & 997,596 \\
\hline Collateral & 5898 & Yes $=1 ; \mathrm{No}=0$ & 0.136 & 0.343 & 0 & 1 \\
\hline Guarantees & 5898 & Yes $=1 ;$ No $=0$ & 0.567 & 0.496 & 0 & 1 \\
\hline \multicolumn{7}{|l|}{ Macroeconomic conditions } \\
\hline Growth & 5898 & Continuous (\%) & 0.149 & 2.147 & -3.071 & 2.292 \\
\hline \multicolumn{7}{|l|}{ Sectors } \\
\hline Primary (control) & 5898 & Yes $=1 ;$ No $=0$ & 0.038 & 0.191 & 0 & 1 \\
\hline Secondary & 5898 & Yes $=1 ; \mathrm{No}=0$ & 0.387 & 0.487 & 0 & 1 \\
\hline Tertiary & 5898 & Yes $=1 ;$ No $=0$ & 0.575 & 0.494 & 0 & 1 \\
\hline \multicolumn{7}{|l|}{ Geographic locations } \\
\hline North & 5898 & Yes $=1 ;$ No $=0$ & 0.324 & 0.468 & 0 & 1 \\
\hline Center & 5898 & Yes $=1 ;$ No $=0$ & 0.318 & 0.466 & 0 & 1 \\
\hline Lisbon and Vale do Tejo & 5898 & Yes $=1 ; \mathrm{No}=0$ & 0.170 & 0.376 & 0 & 1 \\
\hline Alentejo & 5898 & Yes $=1 ;$ No $=0$ & 0.086 & 0.281 & 0 & 1 \\
\hline South (Algarve) & 5898 & Yes $=1 ; \mathrm{No}=0$ & 0.025 & 0.155 & 0 & 1 \\
\hline Madeira & 5898 & Yes $=1 ; \mathrm{No}=0$ & 0.013 & 0.113 & 0 & 1 \\
\hline Azores & 5898 & Yes $=1 ;$ No $=0$ & 0.039 & 0.193 & 0 & 1 \\
\hline Special Administrative Region (control) & 5898 & Yes $=1 ;$ No $=0$ & 0.026 & 0.158 & 0 & 1 \\
\hline \multicolumn{7}{|l|}{ Time-specific effects } \\
\hline 2007 & 5898 & Yes $=1 ; \mathrm{No}=0$ & 0.201 & 0.401 & 0 & 1 \\
\hline 2008 & 5898 & Yes $=1 ;$ No $=0$ & 0.240 & 0.427 & 0 & 1 \\
\hline 2009 & 5898 & Yes $=1 ;$ No $=0$ & 0.276 & 0.447 & 0 & 1 \\
\hline 2010 & 5898 & Yes $=1 ;$ No $=0$ & 0.282 & 0.450 & 0 & 1 \\
\hline \multicolumn{7}{|l|}{ Interactions } \\
\hline Collateral $\times$ high credit score & 5898 & Yes $=1 ;$ No $=0$ & 0.058 & 0.233 & 0 & 1 \\
\hline Collateral $\times$ low credit score & 5898 & Yes $=1 ;$ No $=0$ & 0.009 & 0.096 & 0 & 1 \\
\hline Guarantees $\times$ high credit score & 5898 & Yes $=1 ;$ No $=0$ & 0.249 & 0.433 & 0 & 1 \\
\hline Guarantees $\times$ low credit score & 5898 & Yes $=1 ; \mathrm{No}=0$ & 0.036 & 0.187 & 0 & 1 \\
\hline
\end{tabular}

Default $=1$ if the borrower did not default previously but defaulted after the loan was granted $(0,1)$; high credit score $=1$ if the loan is classified with an internal credit score of AAA to $\mathrm{BB}(0,1)$; medium credit score $=1$ if the loan is classified with an internal credit score of BB- to B- $(0,1)$; low credit score $=1$ if the loan is classified with an internal credit score of CCC to $\mathrm{C}(0,1)$; financial tension $=$ ratio between the loan amount approved by the bank to the firm and the total credit available in the entire financial system for the firm (\%); Tier 1 capital [(total equity - revaluation reserves)/risk-based assets]; size = loan amount, in thousands, measured in euros (in the regressions used as the natural logarithm); collateral $=1$ if the borrower posted firm assets as collateral $(0,1)$; guarantees $=1$ if the borrower posted personal guarantees $(0,1)$; growth $=$ Gross Domestic Product per capita growth (base year $=2011)(\%)$; primary $=1$ if the borrower operates in the primary sector $(0,1)$; secondary $=1$ if the borrower operates in the secondary sector $(0,1)$; tertiary $=1$ if the borrower operates in the tertiary sector $(0,1)$; north $=1$ if the loan is monitored by a bank branch in the Portuguese region "North" $(0,1)$; center $=1$ if the borrower operates in the Portuguese region "Center" $(0,1)$; Lisbon and Vale do Tejo $=1$ if the borrower operates in the Portuguese region "Lisbon and Vale do Tejo" $(0,1)$; Alentejo $=1$ if the borrower operates in the Portuguese region "Alentejo" $(0,1)$; South (Algarve) 1 if the borrower operates in Portuguese region "South (Algarve)" $(0,1)$; Madeira = 1 if the borrower operates in the Portuguese region "Madeira" $(0,1)$; Azores = 1 if the borrower operates in the Portuguese region "Azores" $(0,1)$; Special Administrative Region $=1$ if the borrower operates in the Portuguese "Special Administrative Region" (0,1);2007 = 1 if loan was extended in $2007(0,1) ; 2008=1$ if the loan was extended in 2008 $(0,1)$; $2009=1$ if the loan was extended in $2009(0,1) ; 2010=1$ if the loan was extended in $2010(0,1)$ 


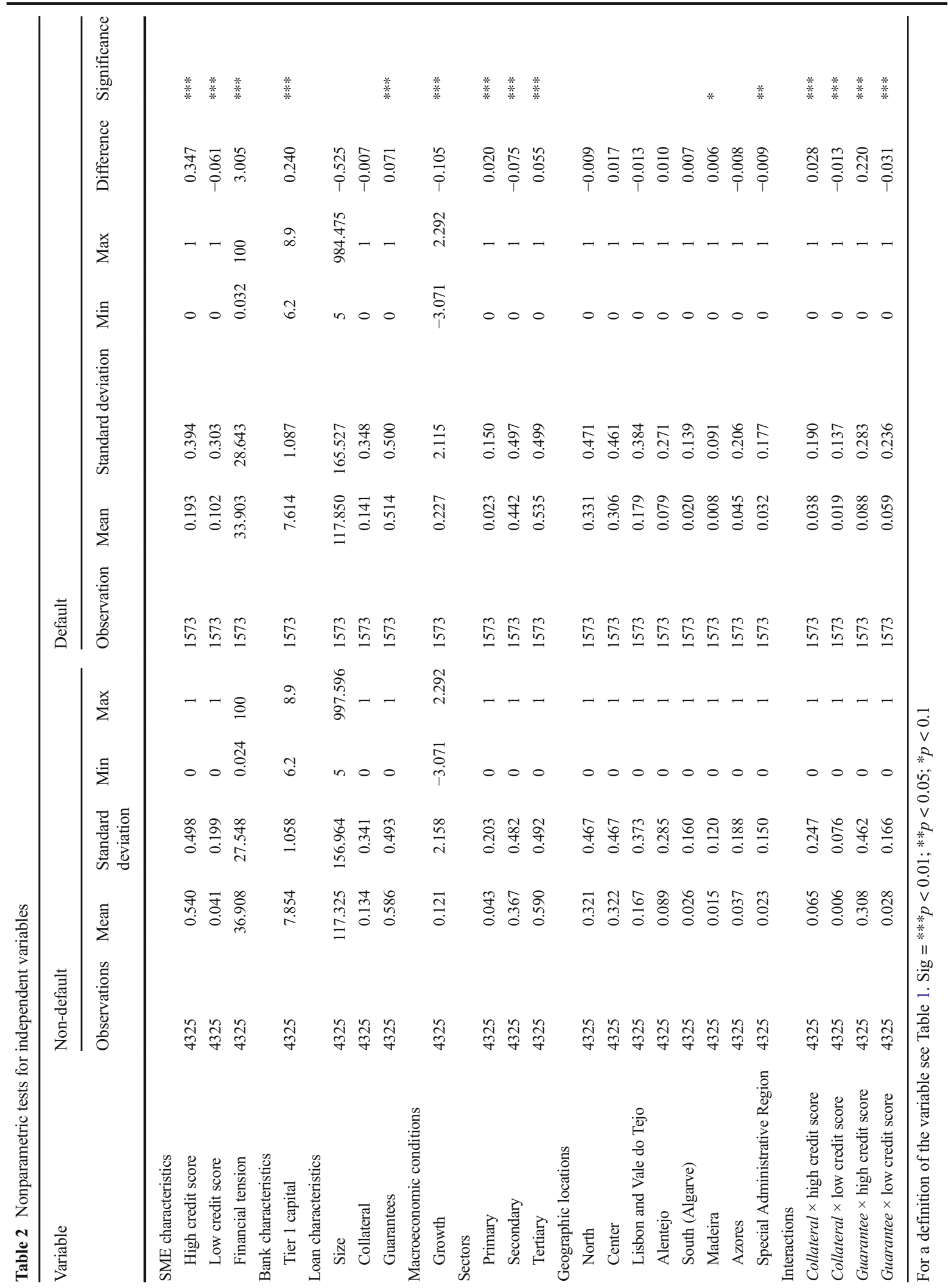




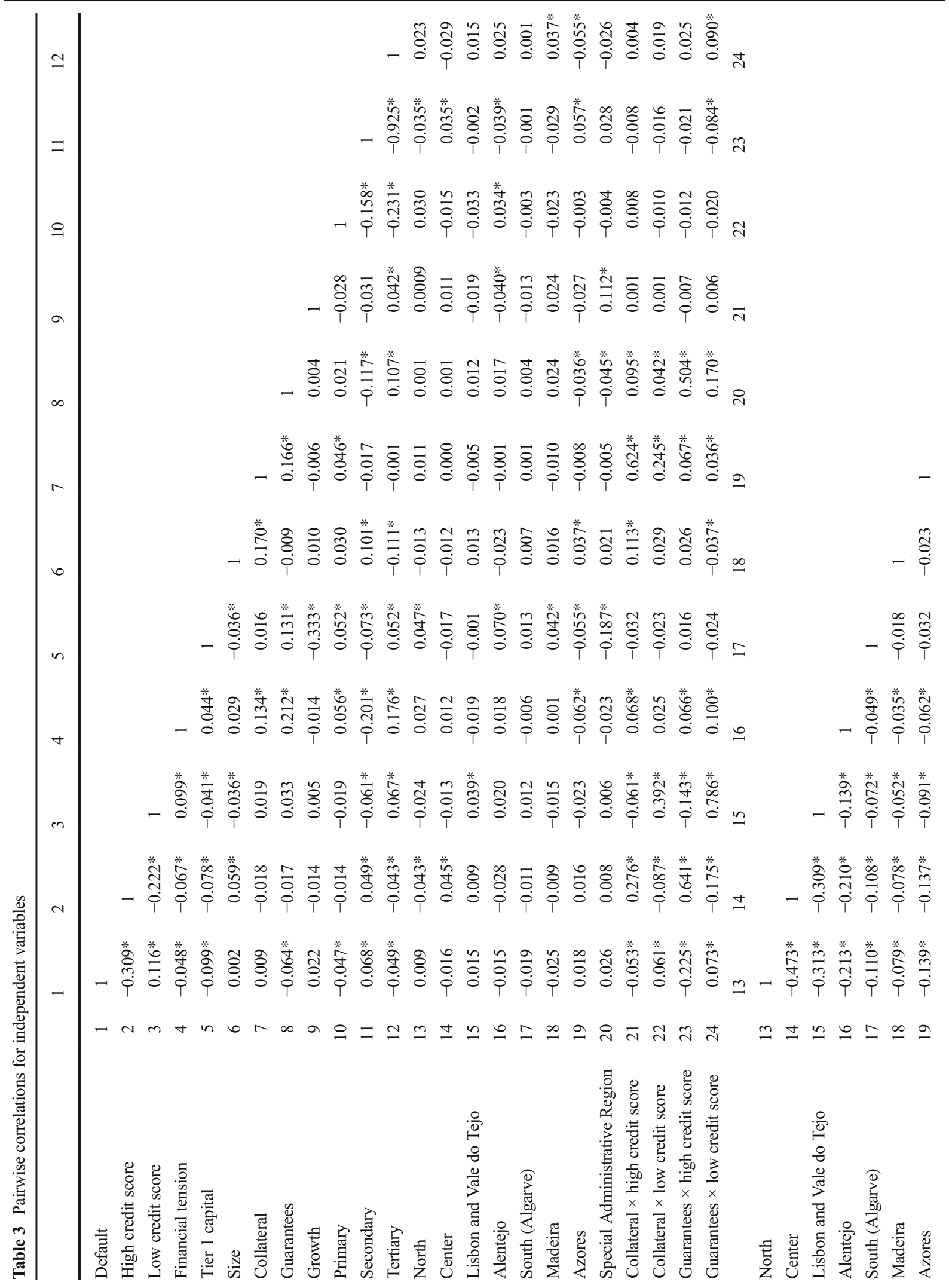




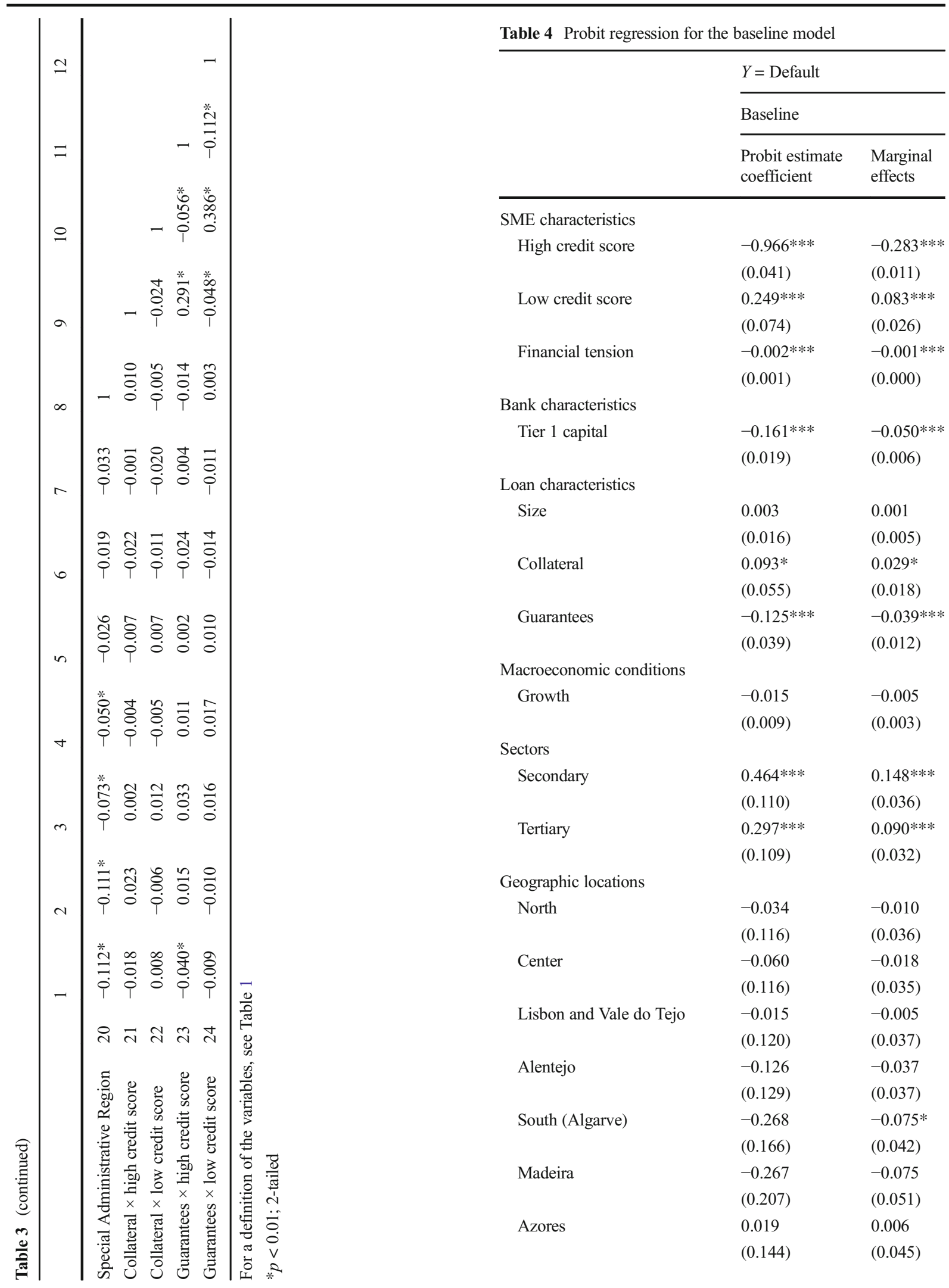


Table 4 (continued)

\begin{tabular}{lll}
\hline & $Y=$ Default \\
\cline { 2 - 2 } & Baseline \\
\cline { 2 - 2 } & $\begin{array}{l}\text { Probit estimate } \\
\text { coefficient }\end{array}$ & $\begin{array}{c}\text { Marginal } \\
\text { effects }\end{array}$ \\
\hline Intercept & $0.790 * * *$ \\
Time-specific effects & $(0.218)$ \\
Predicted probability of default & $23.80 \%$ \\
-2 log likelihood & -3024.340 \\
$N$ & 5898 \\
Cragg-Uhler (Nagelkerke) R2 & 0.183 \\
Maximum likelihood & 0.126 \\
(Cox-Snell) R2 &
\end{tabular}

For the definition of the variables see Table 1. Standard errors are reported between brackets

$* * * p<0.01 ; * * p<0.05 ; * p<0.10$

and $1 \%$ had a low credit score. Regarding the interaction of guarantees, our descriptive statistics reveal that $25 \%$ of SMEs that posted personal guarantees had a high credit score and $4 \%$ had a low credit score.

We report the univariate statistics for our sample, distinguishing between the SMEs that defaulted and those that did not in Table 2. For SMEs that defaulted and SMEs that did not, we find statistically meaningful differences across all variables except loan size and collateral. In this panel, we find statistically meaningful differences in Madeira and the Special Administrative Region. In particular, fewer of the SMEs that defaulted pledged guarantees (51\%) compared to SMEs that did not default (59\%).

In Table 3, we report the correlations for all variables. We do not find linear dependence in our variables to the point of causing any bias in the estimation of our model.

In addition, we also computed the variance inflation factors (VIF) for SME characteristics, namely credit scores (high-1.07; low-1.07) and financial tension (1.02); bank Tier I capital (1.21); loan characteristics, namely, size (1.07), collateral (1.08), and guarantees (1.10); and macroeconomic conditions, namely, growth (1.14). These VIF are very low and reinforce the finding of absence of linear dependence of the variables in Table 3.

\subsection{Method}

We investigate default as a function of the SME (High (low) credit scores and Financial tension), bank (Tier I capital), and loan (Size, Collateral, Guarantees) characteristics, macroeconomic conditions (Growth), and dummies for the sectors (Primary, Secondary, and Tertiary) and geographic locations [North, Center, Lisbon and Vale do Tejo, Alentejo, South (Algarve), Madeira, Azores, and the Special Administrative Region].

Our method involves the testing of hypotheses formulated in Section 3 of this paper, i.e., whether or not the sign and significance of the coefficients reject the hypotheses; the marginal effects to assess the impact of change in independent variables on the dependent variable; and the computation of the predicted probabilities of default with the binary probabilistic model (probit). ${ }^{9}$

We developed one model from the training sample with one-third partition and tested this model on the holdout sample composed of different SMEs or the same SMEs but with different year accounts. We used the training dataset for preliminary model fitting and the holdout sample to assess the model and estimate probabilities of default. We used stratified random sampling to maintain partitioned datasets.

\section{Findings}

We report the findings on default rates in Table 4. In this table, we find a negative relation between high credit score and default (statistically significant at the $1 \%$ level of confidence) and a positive relation between low credit score and default (statistically significant at the $1 \%$ level of confidence). A discrete change in high credit score (from 0 to 1) decreases the probability of default by $28.3 \%$, and a discrete change in low credit score (from 0 to 1 ) increases the probability of default by $8.3 \%$. We do not reject hypotheses $\mathrm{H} 1 \mathrm{a}-\mathrm{H} 1 \mathrm{~b}$. We find a negative relation between Tier I capital and default (statistically significant at the $1 \%$ level of confidence). A unit increase in the Tier I capital decreases the probability

\footnotetext{
${ }^{9}$ Our sample comprises information on new loans to firms. In this sample, we do not have firms that received more than one loan. If we had pooled data, then the generalized estimating equations would certainly be more appropriate.
} 
Table 5 Probit regressions for Collateral $\times$ Credit Scores

\begin{tabular}{|c|c|c|c|c|}
\hline & \multicolumn{4}{|l|}{$Y=$ default } \\
\hline & \multicolumn{2}{|c|}{ A: Collateral $\times$ high credit score } & \multicolumn{2}{|c|}{ B: Collateral $\times$ low credit score } \\
\hline & $\begin{array}{l}\text { Probit estimated } \\
\text { coefficient }\end{array}$ & Marginal effects & $\begin{array}{l}\text { Probit estimated } \\
\text { coefficient }\end{array}$ & Marginal effects \\
\hline \multicolumn{5}{|l|}{ SME characteristics } \\
\hline High credit score & $\begin{array}{l}-1.021 * * * \\
(0.044)\end{array}$ & $\begin{array}{l}-0.298 * * * \\
(0.012)\end{array}$ & $\begin{array}{l}-1.681 * * * \\
(0.074)\end{array}$ & $\begin{array}{l}-0.283^{* * *} \\
(0.011)\end{array}$ \\
\hline Low credit score & $\begin{array}{l}0.254 * * * \\
(0.074)\end{array}$ & $\begin{array}{l}0.084 * * * \\
(0.026)\end{array}$ & $\begin{array}{l}0.382 * * * \\
(0.130)\end{array}$ & $\begin{array}{l}0.074 * * * \\
(0.027)\end{array}$ \\
\hline Financial tension & $\begin{array}{l}-0.002 * * * \\
(0.001)\end{array}$ & $\begin{array}{l}-0.001 * * * \\
(0.000)\end{array}$ & $\begin{array}{l}-0.004 * * * \\
(0.001)\end{array}$ & $\begin{array}{l}-0.001 * * * \\
(0.000)\end{array}$ \\
\hline \multicolumn{5}{|l|}{ Bank characteristics } \\
\hline Tier 1 & $\begin{array}{l}-0.159 * * * \\
(0.019)\end{array}$ & $\begin{array}{l}-0.049 * * * \\
(0.006)\end{array}$ & $\begin{array}{l}-0.269 * * * \\
(0.033)\end{array}$ & $\begin{array}{l}-0.048^{* * *} \\
(0.006)\end{array}$ \\
\hline \multicolumn{5}{|l|}{ Loan characteristics } \\
\hline Size & $\begin{array}{l}0.004 \\
(0.016)\end{array}$ & $\begin{array}{l}0.001 \\
(0.005)\end{array}$ & $\begin{array}{l}0.014 \\
(0.028)\end{array}$ & $\begin{array}{l}0.003 \\
(0.005)\end{array}$ \\
\hline Collateral & $\begin{array}{l}-0.038 \\
(0.068)\end{array}$ & $\begin{array}{l}-0.011 \\
(0.020)\end{array}$ & $\begin{array}{l}0.134 \\
(0.100)\end{array}$ & $\begin{array}{l}0.024 \\
(0.019)\end{array}$ \\
\hline Guarantees & $\begin{array}{l}-0.123 * * * \\
(0.039)\end{array}$ & $\begin{array}{l}-0.038 * * * \\
(0.012)\end{array}$ & $\begin{array}{l}-0.207 * * * \\
(0.066)\end{array}$ & $\begin{array}{l}-0.037 * * * \\
(0.012)\end{array}$ \\
\hline \multicolumn{5}{|l|}{ Macroeconomic conditions } \\
\hline Growth & $\begin{array}{l}-0.015 \\
(0.009)\end{array}$ & $\begin{array}{l}-0.005 \\
(0.003)\end{array}$ & $\begin{array}{l}-0.026 \\
(0.016)\end{array}$ & $\begin{array}{l}-0.005 \\
(0.003)\end{array}$ \\
\hline \multicolumn{5}{|l|}{ Sectors } \\
\hline Secondary & $\begin{array}{l}0.460 * * * \\
(0.110)\end{array}$ & $\begin{array}{l}0.147 * * * \\
(0.036)\end{array}$ & $\begin{array}{l}0.826 * * * \\
(0.197)\end{array}$ & $\begin{array}{l}0.153 * * * \\
(0.038)\end{array}$ \\
\hline Tertiary & $\begin{array}{l}0.289 * * * \\
(0.109)\end{array}$ & $\begin{array}{l}0.088^{* * * *} \\
(0.032)\end{array}$ & $\begin{array}{l}0.537 * * * \\
(0.194)\end{array}$ & $\begin{array}{l}0.093 * * * \\
(0.033)\end{array}$ \\
\hline \multicolumn{5}{|l|}{ Geographic locations } \\
\hline North & $\begin{array}{l}-0.026 \\
(0.116)\end{array}$ & $\begin{array}{l}-0.008 \\
(0.036)\end{array}$ & $\begin{array}{l}-0.028 \\
(0.199)\end{array}$ & $\begin{array}{l}-0.005 \\
(0.035)\end{array}$ \\
\hline Center & $\begin{array}{l}-0.054 \\
(0.116)\end{array}$ & $\begin{array}{l}-0.017 \\
(0.035)\end{array}$ & $\begin{array}{l}-0.069 \\
(0.199)\end{array}$ & $\begin{array}{l}-0.012 \\
(0.035)\end{array}$ \\
\hline Lisbon and Vale do Tejo & $\begin{array}{l}-0.008 \\
(0.120)\end{array}$ & $\begin{array}{c}-0.002 \\
(0.037)\end{array}$ & $\begin{array}{l}0.005 \\
(0.205)\end{array}$ & $\begin{array}{l}0.001 \\
(0.037)\end{array}$ \\
\hline Alentejo & $\begin{array}{l}-0.119 \\
(0.129)\end{array}$ & $\begin{array}{l}-0.036 \\
(0.037)\end{array}$ & $\begin{array}{l}-0.187 \\
(0.221)\end{array}$ & $\begin{array}{l}-0.032 \\
(0.036)\end{array}$ \\
\hline South (Algarve) & $\begin{array}{l}-0.260 \\
(0.167)\end{array}$ & $\begin{array}{l}-0.073 * \\
(0.042)\end{array}$ & $\begin{array}{l}-0.431 \\
(0.287)\end{array}$ & $\begin{array}{l}-0.068 * \\
(0.040)\end{array}$ \\
\hline Madeira & $\begin{array}{l}-0.251 \\
(0.208)\end{array}$ & $\begin{array}{l}-0.071 \\
(0.052)\end{array}$ & $\begin{array}{l}-0.477 \\
(0.369)\end{array}$ & $\begin{array}{l}-0.074 \\
(0.049)\end{array}$ \\
\hline Azores & $\begin{array}{l}0.025 \\
(0.144)\end{array}$ & $\begin{array}{l}0.008 \\
(0.045)\end{array}$ & $\begin{array}{l}0.063 \\
(0.245)\end{array}$ & $\begin{array}{l}0.011 \\
(0.045)\end{array}$ \\
\hline
\end{tabular}


Table 5 (continued)

\begin{tabular}{|c|c|c|c|c|}
\hline & \multicolumn{4}{|l|}{$Y=$ default } \\
\hline & \multicolumn{2}{|c|}{ A: Collateral $\times$ high credit score } & \multicolumn{2}{|c|}{ B: Collateral $\times$ low credit score } \\
\hline & $\begin{array}{l}\text { Probit estimated } \\
\text { coefficient }\end{array}$ & Marginal effects & $\begin{array}{l}\text { Probit estimated } \\
\text { coefficient }\end{array}$ & Marginal effects \\
\hline \multirow[t]{2}{*}{ Interactions } & $0.383 * * * a$ & $0.131 * * *$ & $0.178^{b}$ & 0.033 \\
\hline & $(0.111)$ & $(0.041)$ & $(0.317)$ & $(0.062)$ \\
\hline \multirow[t]{2}{*}{ Intercept } & $0.788 * * *$ & & $1.252 * * *$ & \\
\hline & $(0.219)$ & & $(0.377)$ & \\
\hline Time-specific effects & Yes & & Yes & \\
\hline Predicted probability of default & $23.74 \%$ & & $23.81 \%$ & \\
\hline-2 log likelihood & -3018.507 & & -3024.153 & \\
\hline$N$ & 5898 & & 5898 & \\
\hline Cragg-Uhler (Nagelkerke) R2 & 0.186 & & 0.183 & \\
\hline Maximum likelihood (Cox-Snell) R2 & 0.127 & & 0.126 & \\
\hline
\end{tabular}

For the definition of the variables see Table 1. Standard errors are reported between brackets

$* * * p<0.01 ; * * p<0.05 ; * p<0.10$

${ }^{\mathrm{a}}$ The coefficient obtained from the linear combination of the interaction is $-0.676(0.087)^{* * *}$

${ }^{b}$ The coefficient obtained from the linear combination of the interaction is $0.432(0.174)^{* *}$

of default by $5.0 \%$. We do not reject hypothesis $\mathrm{H} 2$. We find a positive relation between collateral and default (statistically significant at the $10 \%$ level of confidence).$^{10} \mathrm{~A}$ discrete change in collateral (from 0 to 1 ) increases the probability of default by $2.9 \%$. We reject hypothesis $\mathrm{H} 4 \mathrm{a}$. We find a negative relation between guarantees and default (statistically significant at the $1 \%$ level of confidence). A discrete change in the guarantees (from 0 to 1 ) decreases the probability of default by $3.9 \%$. We do not reject hypothesis $\mathrm{H} 4 \mathrm{~b}$. With respect to sectors, we find a positive relation between the secondary and tertiary and default (statistically significant at the $1 \%$ level of confidence). Discrete changes in the secondary and tertiary sectors (from 0 to 1 ) increase the probability of default by 14.8 and $9 \%$. We do not reject hypotheses $\mathrm{H} 6 \mathrm{~b}-\mathrm{c}$. With respect to regions, we find a negative relation between South (Algarve) and default (statistically significant at the $10 \%$ level of confidence). A discrete change in the region South (Algarve) reduces

\footnotetext{
${ }^{10}$ This finding is surprising albeit at the $10 \%$ level of confidence. In unreported regression, we re-estimated this (and other) models with data for only 2008-2009 and the relation between collateral and default ceased to be significant at a statistically meaningful level.
}

the probability of default by $7.5 \%$. We do not reject hypothesis $7 \mathrm{e}^{11}$

5.1 Interaction of collateral (guarantees) and high(low) credit score

To ascertain the joint influence of collateral (guarantees) with high(low) credit score SMEs, we re-estimated our baseline model, including the interaction variables. We report the findings of these estimations in Table 5 (collateral), panel A (high credit score) and panel B (low credit score); and Table 6 (guarantees), panel A (high credit score) and panel B (low credit score). We focus our analyses on the coefficients and marginal effects obtained from the linear combination of the independent variables of interest. In Table 5, panel A, we find a negative relation between collateral $\times$ high credit score and default (statistically significant at the $1 \%$ level of confidence). A discrete change in the

\footnotetext{
${ }^{11}$ We find a negative relation between financial tension and default. However, its magnitude and consequently economic impact is extremely low; the marginal effect of a unit increase in financial tension on default is $0.01 \%$. One possible explanation is that SMEs that are too exposed to a single bank default less to avoid the negative implication for their main banking relationship. This is a promising area for future research.
} 
Table 6 Probit regressions for Guarantees $\times$ Credit Scores

$Y=$ default

A: Guarantees $\times$ high credit score

B: Guarantees $\times$ low credit score

Probit estimated coefficient Marginal effects

Probit estimated coefficient Marginal effects

SME characteristics

High credit score

Low credit score

Financial tension

Bank characteristics

Tier 1 capital

$-0.269 * * *$

(0.033)

Loan characteristics

Size

0.014

(0.028)

Collateral

0.150

(0.095)

Guarantees

$-0.163 * *$

(0.077)

Macroeconomic conditions

Growth

-0.026
$(0.016)$

Sectors

Secondary

$0.832 * * *$

Tertiary

(0.197)

$0.543 * * *$

(0.194)

Geographic locations

North

$-0.029$

(0.199)

Center

$-0.071$

(0.199)

Lisbon and Vale do Tejo

0.007

(0.205)

Alentejo

$-0.185$

(0.221)

South (Algarve)

$-0.427$

(0.287)

Madeira

$-0.493$

(0.369)

Azores

Interactions

\subsection{6}

(0.245)

$-0.166^{* * * a}$

$\begin{array}{ll}-0.269 * * * & -1.680 * * * \\ (0.016) & (0.074) \\ 0.079 * * * & 0.499 * * * \\ (0.025) & (0.192) \\ -0.001 * * * & -0.004 * * * \\ (0.000) & (0.001)\end{array}$

$-0.269 * * *$

$-0.048 * * *$

(0.033)

$-0.048 * * *$

(0.006)

0.003

(0.005)

0.027

(0.018)

$-0.035^{* * *}$

(0.012)

(0.014)

(095)

-0.196 ***

(0.069)

$-0.005$

$-0.005$

$-0.026$

(0.003)

(0.016)

$0.154 * * *$

$0.154 * * *$

$0.829 * * *$

(0.038)

(0.038)

(0.197)

$0.094 * * *$

(0.033)

(0.195)

(0.033)

$-0.005$

$-0.027$

$-0.005$

(0.035)

(0.199)

(0.035)

$-0.013$

$-0.069$

$-0.012$

(0.199)

(0.035)

0.001

(0.037)

(0.205)

$-0.032$

(0.036)

-0.068 *

(0.040)

$-0.075$

(0.049)

0.012

(0.045)

(0.045)

(0.245)

$-0.024$ 
Table 6 (continued)

\begin{tabular}{|c|c|c|c|c|}
\hline & \multicolumn{4}{|l|}{$Y=$ default } \\
\hline & \multicolumn{2}{|c|}{ A: Guarantees $\times$ high credit score } & \multicolumn{2}{|c|}{ B: Guarantees $\times$ low credit score } \\
\hline & Probit estimated coefficient & Marginal effects & Probit estimated coefficient & Marginal effects \\
\hline \multirow{3}{*}{ Intercept } & $(0.144)$ & $(0.024)$ & $(0.240)$ & $(0.040)$ \\
\hline & $1.225 * * *$ & & $1.247 * * *$ & \\
\hline & $(0.378)$ & & $(0.377)$ & \\
\hline Time-specific effects & Yes & & Yes & \\
\hline Predicted probability of default & $23.79 \%$ & & $23.09 \%$ & \\
\hline-2 log likelihood & -3024.167 & & -3024.113 & \\
\hline$N$ & 5898 & & 5898 & \\
\hline Cragg-Uhler (Nagelkerke) R2 & 0.183 & & 0.183 & \\
\hline Maximum likelihood (Cox-Snell) R2 & 0.126 & & 0.126 & \\
\hline
\end{tabular}

For the definition of the variables see Table 1. Standard errors are reported between brackets

$* * * p<0.01 ; * * p<0.05 ; * p<0.10$

${ }^{a}$ The coefficient obtained from the linear combination of the interaction is $-1.097(0.058)^{* * *}$

${ }^{\mathrm{b}}$ The coefficient obtained from the linear combination of the interaction is $0.094(0.094)$

interaction term decreases the probability of default by 8.7\%. We do not reject hypothesis H4c1. In Table 5, panel $\mathrm{B}$, we find a positive relation between collateral $\times$ low credit score (statistically significant at $5 \%$ ). Thus, a discrete change in the interaction term increases the probability of default by $17.4 \%$. We do not reject hypothesis H4c2. In Table 6, panel A, we find a negative relation between guarantees $\times$ high credit score and default (statistically significant at the $1 \%$ level of confidence). A discrete change in the interaction term decreases the probability of default by $5.8 \%$. Again, we do not reject hypothesis H4d1 for guarantees. Surprisingly though, in Table 6, panel B, we do not find a statistically significant relation between guarantees $x$ low credit score. We do not accept hypothesis $\mathrm{H} 4 \mathrm{~d} 2$ for guarantees. As the findings for sectors and regions are identical to the baseline, we do not reject hypotheses H6b-c and H7e.

\subsection{Forecasting performance}

We evaluated the quality of the forecast with the ROC curve. We report the findings in Table 7 panel A1 for the full sample and panel B2 for the holdout sample. In panel A1, we find that the area under the curve is $73.2 \%$, whereas in panel A2 it is $77.2 \%$. These values indicate the very good discriminatory ability of our model.
We evaluated the potential biases in the classification of SMEs in the model: if a defaulting SME is wrongly classified as non-defaulting (Type I) and if a nondefaulting SME is wrongly classified as defaulting (Type II). We report the findings in Table 8 panel B1 for the full sample and panel B2 for the holdout sample. Regarding cut-off values, SMEs above 0.5 are classified as defaulting and SMEs below or equal to 0.5 are classified as non-defaulting. For example, for a cut-off value of 0.5 , in panel A1, the model generates an overall correct classification of 74\%; and in panel A2, the model generates an overall classification of $73 \%$. Reducing the cut-off decreases the number of times that a defaulting SME is incorrectly classified as a nondefaulting SME (Type I error). For example, for a cut-

Table 7 Forecasting performance of the model. Area under the ROC curve

\begin{tabular}{lll}
\hline & $\begin{array}{l}\text { Panel A1 } \\
\text { Full sample }\end{array}$ & $\begin{array}{l}\text { Panel A2 } \\
\text { Holdout sample }\end{array}$ \\
\hline$N$ & 5898 & 4719 \\
Area & 0.732 & 0.772 \\
Standard error & 0.007 & 0.007 \\
95\% Confidence interval & {$[0.718 ; 0.746]$} & {$[0.758 ; 0.786]$} \\
$\quad$ lower; upper $]$ & & \\
\hline
\end{tabular}


Table 8 Forecasting perfomance of the model. Error classification

\begin{tabular}{|c|c|c|c|c|c|c|}
\hline \multirow[b]{2}{*}{ Cut-off } & \multicolumn{3}{|c|}{ Panel B1: Full sample (\%) } & \multicolumn{3}{|c|}{ Panel B2: Full sample (\%) } \\
\hline & Type I & Type II & Correct & Type I & Type II & Correct \\
\hline 0.5 & 81.755 & 5.595 & 74.093 & 56.898 & 12.397 & 72.770 \\
\hline 0.06 & 0.826 & 96.486 & 29.027 & 1.208 & 93.134 & 37.508 \\
\hline 0.05 & 0.445 & 98.775 & 27.450 & 0.509 & 97.139 & 35.071 \\
\hline 0.04 & 0.064 & 99.607 & 26.941 & 0.254 & 98.951 & 33.948 \\
\hline
\end{tabular}

off value of 0.06 , in panel B1, the model generated an overall correct classification of $29 \%$; and in panel B2, the model generates an overall classification of $38 \%$. These are extremely good classifications since we did not construct artificially matched samples of defaulting and non-defaulting SMEs.

Last but not the least, we evaluated the predictive ability of the model by assessing default rates. We report the findings in Table 9, panel $\mathrm{C} 1$ for the full sample and $\mathrm{C} 2$ for the holdout sample. In panel C2 (C1), the average default rate for SMEs that posted collateral is $34.2 \%$ (27.7\%), while for SMEs that did not do so is $33.2 \%$ (26.5\%); the difference of $-1 \%(-1.2 \%)$ is statistically non-significant at a meaningful level. But in panel C2 (C1), the average default rate for SMEs that pledged guarantees is $29.9 \%$ (24.2\%), while for SMEs that did not do so it is $38 \%(29.9 \%)$; the difference of $-8.1 \%$ $(-5.7 \%)$ is statistically significant at the $1 \%$ level of confidence. The predicted rate of default for SMEs that pledged guarantees is lower than that for SMEs that did not do so.

Focusing now on the interaction of collateral with credit scores, in panel $\mathrm{C} 2(\mathrm{C} 1)$, the average default rate for SMEs that posted collateral and had a high credit score is $21.5 \%$ (17.3\%), while for SMEs that posted collateral but did not have a high credit score is $34.1 \%$ (27.2\%); the difference of $-12.6 \%(-9.9 \%)$ is statistically significant at the $1 \%$ level of confidence. In panel C2 (C1), the average default rate for SMEs that posted collateral and had a low credit score is $66.7 \%$ (54.5\%), while for SMEs that posted collateral but did not have a low credit score is $33.0 \%$ (26.4\%); the difference of $33.7 \%(28.1 \%)$ is statistically significant at the $1 \%$ level of confidence.

Analogously, focusing now on the interaction of guarantees with credit scores, in panel C2 (C1), the average default rate for SMEs that pledged guarantees and had a high credit score is $11.9 \%$ (9.4\%), while for SMEs that pledged guarantees but did not have a high credit score is $40.3 \%$ (32.4\%); the difference of $-28.4 \%$ $(-23 \%)$ is statistically significant at the $1 \%$ level of confidence. In panel $\mathrm{C} 2(\mathrm{C} 1)$, the average default rate for SMEs that pledged guarantees and had a low credit score is $54.4 \%$ (43.3\%), while for SMEs that pledged guarantees but did not have a low credit score is $32.5 \%$ (26.0\%); the difference of $21.9 \%(17.3 \%)$ is statistically significant at the $1 \%$ level of confidence. These findings show a strong predictive relation between collateral (guarantees) and default, and between collateral (guarantees) and credit scores jointly and default.

\section{Summary, conclusions, and implications}

We extend the existing literature on the role of owner liability recently pioneered by Bhimani et al. (2014) in the prediction of default in bank loans to SMEs. In particular, we use unique and proprietary data to investigate the role of collateral and guarantees alongside SME, bank and loan characteristics, macroeconomic conditions, sectors, and geographic locations while controlling for unobserved time effects in predicting default at the peak of the 2007-2009 financial crisis.

Our proprietary data refers to a large bank operating in the commercial and retail segment in Portugal; unlike the USA, Portugal experienced an exceptional macroeconomic policy framework during the recent financial crisis, has a bank-dominated financial infrastructure with very low separation of ownership and control where SMEs are less able to tap into capital markets to raise equity and debt, and has very weak legal rights and large (long) contract enforcement costs (periods).

The analyses of our data show that only a fraction of loans granted to SMEs at the peak of the financial crisis were secured with collateral, which in our context is most commonly associated with the aforementioned legal rights and contract enforcement costs and periods. In testing our hypotheses, we first focus on the relation 


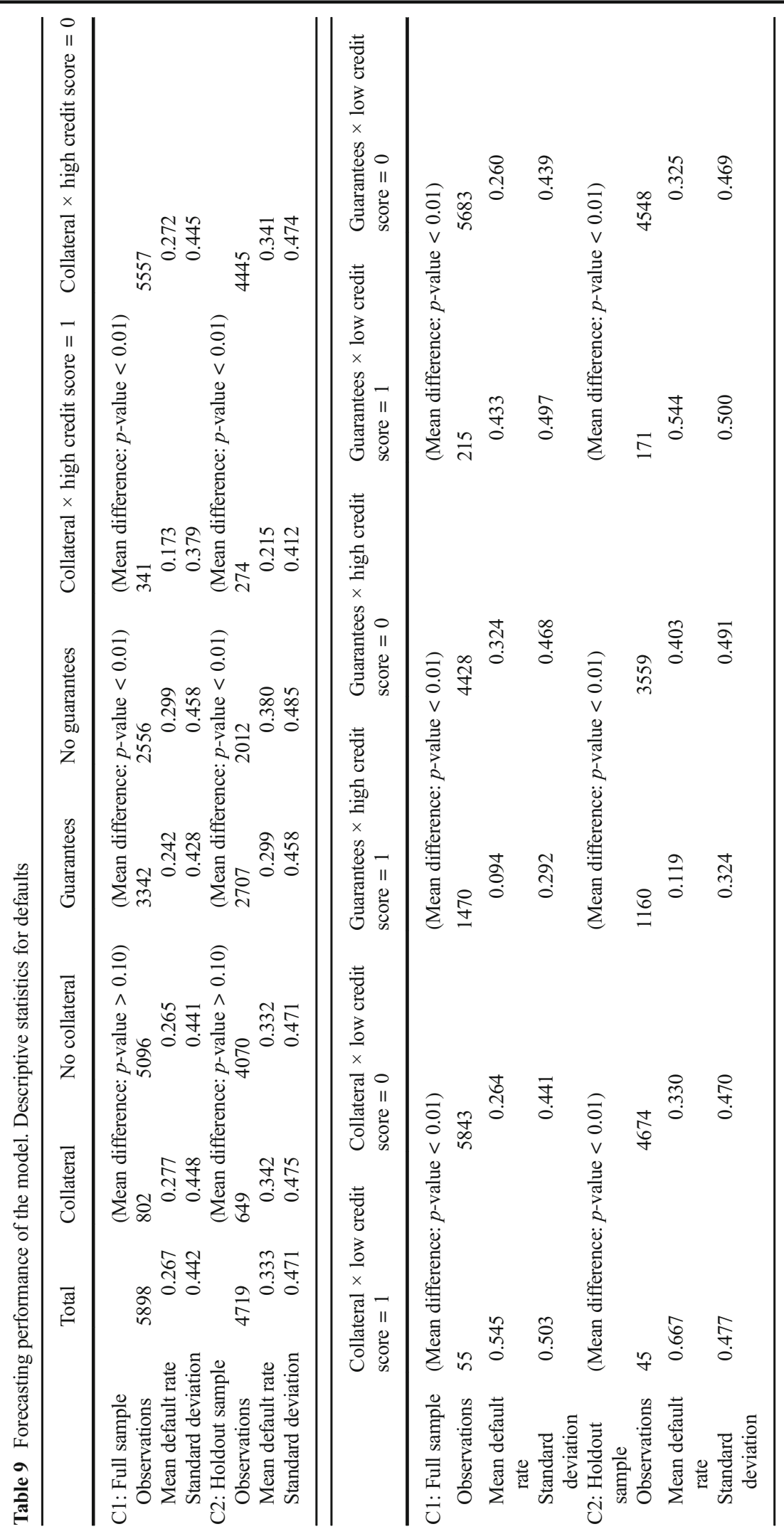


between collateral and guarantees and default. We find an unexpected positive relation between collateral and default, and the expected negative relation between guarantees and default. In the case of guarantees, the finding is in line with our hypothesis. In the case of collateral, as we see below, the unexpected positive relation with default holds for low credit score SMEs. Next, we focus on the joint influence of collateral and guarantees, and credit scores of SMEs. We find a negative relation between the joint influence of collateral and guarantees and high credit score, and a positive relation between the joint influence of collateral and low credit score and default. Both collateral and guarantees reduced default rates for better quality SMEs, in line with the hypothesis that better quality firms provide collateral and guarantees as a signal of their commitment to make more effort and to take fewer risks.

During the financial crisis, macroeconomic policies, in particular those spearheaded by the ECB and the EIB, were designed not only to unlock growth in ailing economies by facilitating access to credit by SMEs but also to safeguard the solvability and liquidity of the banking systems by reducing the potential impact of defaults on loans extended to SMEs. Our findings indicate through our data on the proportion of loans granted with collateral and guarantees that personal guarantees of owners and managers appear to have eased the implementation of these policies at the peak of the financial crisis and, in particular, significantly reduced defaults in bank loans to SMEs.

Our findings show that the binary probabilistic model deployed here and the variables used to relate SME and loan characteristics, macroeconomic conditions, sectors and geographic locations, to default can be of critical use to banks. Banks can use the method and the findings in the risk management of their banking book and in the calculation of minimum capital required under the Basel Capital Accords. Supervisory authorities can use the method and the factors that determine default to detect early warning signals in bank loan portfolios of the type used in this study; and regulatory authorities can use the method and the probability of default across similar bank loan portfolios to assess pressure in the corporate sector.

Our findings show that the main hypotheses explaining defaults in bank loans to SMEs developed and tested in the context of stable macroeconomic setting are, in general, applicable to the context of financial crisis, although in the latter case the observed default rates are particularly high and the relation between collateral and default is quite unexpected. This being said, our findings highlight the critical role played by personal guarantees in facilitating access to bank loans and reducing defaults in bank loans at the peak of the financial crisis. On the one hand, personal guarantees may facilitate access to credit and reduce the costs associated with posting collateral, which may be particularly relevant for young entrepreneurs that lack credit history and operate in sectors that rely extensively on intangible assets (The Economist 2014). On the other hand, however, personal guarantees lock-in the effort and prudence of owners by altering the structure of their liability. Unlike collateral, which limits the downside risk of owners while preserving the upside potential, guarantees increase the liability of owners to an unlimited extent, i.e., beyond business and including personal assets, making owners of SMEs more susceptible to personal bankruptcy (Bhimani and Ncube 2006). This personal bankruptcy or unlimited liability is at odds with the tenant of corporate bankruptcy or limited liability that is at the core of the theory of financial economics. This highly undesirable risk for owners of SMEs deserves further investigation both from a theoretical and empirical perspective.

Acknowledgements Authors and institutions are in alphabetical order. The views expressed in this paper are those of the authors and do not necessarily represent the views of the institutions with which they are affiliated. The authors acknowledge financial, research and administrative support from the FCT (ISCTE-IUL: UID/GES/00315/2013; FDD \& APMG: NECE: UID/GES/04630/ 2013). Corresponding author: Ana Paula Matias Gama, Professor UBI Portugal. E-mail: amatias@ubi.pt.

\section{References}

Abreu, J. F., \& Gulamhussen, M. A. (2013). Dividend payouts: evidence from U.S. bank holding companies in the context of the financial crisis. Journal of Corporate Finance, 22(1), 54-65.

Ang, J., Lin, J., \& Tyler, F. (1995). Evidence on the lack of separation between business and personal risks among small businesses. Journal of Small Business Finance, 4, 197-210.

Avery, R. B., Bostic, R., \& Samolyk, K. (1998). The role of personal wealth in small business finance. Journal of Banking \& Finance, 22, 1019-1061.

Bartoli, F., Ferri, G., Murro, P., \& Rotondi, Z. (2013). Bank-firm relations and the role of mutual guarantee institutions at the peak of the crisis. Journal of Financial Stability, 9(1), 90-104.

Berger, A., \& Udell, F. G. (2002). Small business credit availability and relationship lending: the importance of bank organization structure. Economic Journal, 112(477), 32-53. 
Bester, H. (1985). Screening vs. rationing in credit markets with imperfect information. American Economic Review, 75(4), $850-855$.

Bhimani, A., \& Ncube, M. (2006). Virtual integration costs and the limits of supply chain scalability. Journal of Accounting and Public Policy, 25(4), 390-408.

Bhimani, A., Gulamhussen, M. A., \& Lopes, S. R. (2014). Owner liability and financial reporting information as predictors of firm default in bank loans. Review of Accounting Studies, 19, 769-804.

Butera, G., \& Faff, R. (2006). An integrated multi-model credit rating systems for private firms. Review of Quantitative Finance and Accounting, 27(3), 311-340.

Chan, Y., \& Kanatas, G. (1985). Asymmetric valuation and the role of collateral in loan agreements. Journal of Money, Credit and Banking, 17, 85-95.

Derban, W. K., Binner, J. M., \& Mullineux, A. (2005). Loan repayment performance in community development finance institutions in the UK. Small Business Economics, 25(4), 319.

Dietrich, J. R., \& Kaplan, R. S. (1982). Empirical analysis of the loan classification decision. The Accounting Review, 57(1), $18-38$.

Duffie, D., \& Singleton, K. (2003). Credit risk: pricing, measurement and management. Princeton, NJ: Princeton University Press.

European Central Bank (ECB). (2010). Surveying the access to finance small and medium-sized enterprises in the Euro area: second half of 2009. Frankfurt: European Central Bank.

European Commission (EC). (2003). Commission recommendation of 6 May 2003 (2003/361/EC) concerning the definition of micro, small and medium-sized enterprises. Official Journal of the European Union (L124/39), 124, 36-41.

Gama, A. P., \& Van Auken, H. (2015). The interdependence between trade credit and bank lending: commitment in intermediary firm relationships. Journal of Small Business Management, 53(4), 886-904.

Glantz, M., \& Mun, J. (2008). The banker's handbook on credit risk: implementing Basel II. Amsterdam: Academic Press.

Grunert, J., \& Norden, L. (2012). Bargaining power and information SME lending. Small Business Economics, 39(2), 401-417.

Haughwout, A., Okah, E. and Tracy, I. (2009). Second chances: subprime mortgage modifications and re-default. Federal Reserve Bank of New York Staff Report no. 417. https://doi.org/10.2139/ssrn.1527870
Holmstrom, B., \& Tirole, J. (1997). Financial intermediation, loanable funds, and the real sector. Quarterly Journal of Economics, 62, 663-691.

Jacobson, T., Lindé, J., \& Roszbach, K. (2005). Credit risk versus capital requirements under Basel II: are SME loans and retail credit really different? Journal of Financial Services Research, 28(1), 43-75.

Krivogorsky, V. (2011). Law, corporate governance and accounting: European perspectives. London: Routledge.

Laitinen, E. (1992). Prediction of failure of a newly founded firm. Journal of Business Venturing, 7(4), 323-340.

Menkhoff, L., Neuberger, D., \& Rungruxsirivorn, O. (2012). Collateral and its substitutes in emerging markets' lending. Journal of Banking \& Finance, 36, 817-834.

Ono, A., \& Uesugi, I. (2009). Role of collateral and personal guarantees in relationship lending: evidence from Japan's SME loan market. Journal of Money, Credit and Banking, 41(5), 935-960.

Peltoniemi, J., \& Vieru, M. (2013). Personal guarantees, loan pricing, and lending structure in Finnish small business loans. Journal of Small Business Management, 51, 235-255.

Saurina, J., \& Trucharte, C. (2004). The impact of Basel II on lending to small- and medium-size firms: a regulatory policy assessment based on Spanish credit register data. Journal of Financial Services Research, 26(2), 121-144.

Siddiqi, N. (2006). Credit risk scorecards: developing and implementing intelligent credit scoring. New Jersey: John Wiley.

Stiglitz, J. E., \& Weiss, A. (1981). Credit rationing in markets with imperfect information. American Economic Review, 71(3), 393-410.

Stulz, R., \& Johnson, H. (1985). An analysis of secured debt. Journal of Financial Economics, 14(4), 501-521.

The Economist. (2014). Fixing finance. Portugal: The Lisbon Summit. Lisbon.

The World Bank. (2017). World development indicators. United States: Washington.

Voordeckers, W., \& Steijvers, T. (2006). Business collateral and personal commitments in SME lending. Journal of Banking \& Finance, 30, 3067-3086.

Westgaard, S., \& Wijst, N. (2001). Default probabilities in a corporate bank portfolio: a logistic model approach. European Journal of Operational Research, 135(2), 338-349. 